Nepalese Culture

Vol. XIV : 1-12, 2021

Central Department of NeHCA,

Tribhuvan University, Kathmandu, Nepal

DOI: https://doi.org/10.3126/nc.v14i0.35187

\title{
River Culture in Nepal
}

\author{
Kamala Dahal- Ph.D \\ Associate Professor, \\ Patan Multipal Campus, T.U. \\ E-mail: kamala.dahal@pmc.tu.edu.np
}

\begin{abstract}
Most of the world civilizations are developed in the river basins. However, we do not have too big rivers in Nepal, though Nepalese culture is closely related with water and rivers. All the sacraments from birth to the death event in Nepalese society are related with river. Rivers and ponds are the living places of Nepali gods and goddesses. Jalkanya and Jaladevi are known as the goddesses of rivers. In the same way, most of the sacred places are located at the river banks in Nepal. Varahakshetra, Bishnupaduka, Devaghat, Triveni, Muktinath and other big Tirthas lay at the riverside. Most of the people of Nepal despose their death bodies in river banks. Death sacrement is also done in the tirthas of such localities. In this way, rivers of Nepal bear the great cultural value. Most of the sacramental, religious and cultural activities are done in such centers. Religious fairs and festivals are also organized in such a places. Therefore, river is the main centre of Nepalese culture.
\end{abstract}

Key words: sacred, sacraments, purity, specialities, bath.

\section{Introduction}

The geography of any localities play an influencing role for the development of culture of a society. It affects a society directly and indirectly. In the beginning the nomads passed their lives for thousands of year in the jungle. Although they contacted to the big rivers for the collection of drinking water, they used to move on forest for the hunt. However, forest animals also used to reach at river basin to get water. In this way, rivers were the centre of drinking water for both man and animal. Therefore, the animals of the jungle were also depended in the river water. They could get water and most the grass-eating animals used to reach at the riverside for drinking water each day. In this way, rivers were the centres for both people and the animals. 
Rivers are important for the people of different religion, faith and culture. Most of the big cities are located in the river basin. Drinking water, security and open environment were the main reason for the development of settlement in river basin. Therefore, the ancient man established a close relation with water. Latter on each activities of a man were related with river. It is a main reason of affecting the culture of people by the river. Most of the ancient civilizations were developed in the riverbanks. Latter on his relation with the river was continuous and most of his activities were related with water and river.

Nepal is divided into mountain, hills and the low land. Hence, the people of different region bear different culture. It is due to the effect of geography. Availability of the forest and the findings of mines and minerals also affect the life style of the people. Natural vegetations also affects the culture of the people. Therefore, natural resources affect the culture and society of the people.

We do not know the actual date of the origin of man. However, it is assumed that man was originated at the central part of Asia. In the beginning, man travelled different places for the long time. Latter on he started to settle at the banks of the river from 3500 BC. Social organizations were also established after that process. Such civilizations were developed from Indus Valley to the Egypt. Fertile land, suitable climate and geographically low land were suitable places for the development of human civilization. Human being started the political system from the period of civilization. Civilization was started from the ending of Neolithic age. After the invention of metal, man discovered facilities and people migrated different places. However, his relation with river was maintained regularly. Therefore, all kind of activities are correlated with rivers. People living far way from the rivers also is related with rivers.

The culture developed at the bank of the rivers is called river culture. River culture was developed at the time of civilization. Therefore, old historical evidences are found in river valley. For example, big cities like Banaras, Calcutta and other cities were developed in riverbanks. Big cities are located at the bank of rivers even today.

The Hindus consider rivers as goddesses. Therefore, they are taken as sacred centers. Many people go to the river side in different occasions, feasts and festivals to take sacred bath. Different kind of sacramental and religious activities are performed in river banks after the bath. In the same way, rivers are the centers of worship in the name of Ganga. Ganga is the daughter of Bhagiratha and the wife of lord Shiva according to the Puranas. In the other hand, rivers are taken as Jaldevi. Some ethnic group of people in Nepal worships her with macassaring birds and animals.

We do not have big rivers in Nepal like India, Pakistan, Egypt and Iraq and we cannot find the archaeological remains of ancient civilization in these river basins. However, we 
have some rivers, which are more important for the development of culture and civilization. Koshi, Gandaki and Karnali are main three big rivers of Nepal. Among them Koshi is the biggest, Gandaki is the deepest and the Karnali is the longest. Koshi river originates from Tibet and reaches to the Ganga of India. Other rivers like Gandaki and Karnali also originate from Tibet, flow through India and reach up to Ganga. Arun and Bhote or Tamba Koshi of Koshi river and Humla Karnali branch of Karnali river are originated from Tibet. In the same way, all the rivers of Nepal reach up to Ganga river of India and flow towards Bangladesh.

\section{Rivers of Nepal}

We have three catagories of river according to their sources. The first category of rivers originate from Himalayan region. Koshi, Gandaki and Karnali are the main rivers of first category. Each of them have seven branches and they are called Sapta Koshi (Seven Koshi), Sapta Gandaki (seven Gandaki) and Sapta Karnali (Seven Karnali). They flow from east, middle and western part of Nepal respectively. They originate from the high mountain and most of them are full of water in all the seasons. However, some of their branches are originated from Tibet also. Only a few rivers are originated from Mahabharat or Chure region of Nepal. Most of these rivers flow from north to south direction.

The first kind of rivers are originated from the Himalayas, Glaciers, Snow Mountains and lakes, which has permanent source of water. The water flows all seasons of the year in such rivers. The main big three rivers are catagoried inside this group. In the same way, second catagories of the river originates from the middle hill region. They also are the source of water for terai region. They also join the big rivers and flow down towards the low land. We can find water flowing even in the dry season in such rivers.

Mechi, Kankai, Kamala, Bagmati, Rapti, Babai, Trijuga, Koka, Kabeli, Teliya, Lambu, Pinguwa, Koyakhola, Banchare Khola, Sabhakhola, Piluwa, Tinau, Banganga, Chepe and Paundikhola are some examples of second catagories rivers of Nepal. They originate from the Mahabharata range and join to the big rivers. Some of them reach the Ganges directly. Some of them adjoin the big rivers in the hills and others reach up to the low land and flow towards the Ganga River. Most of these rivers mix with big rivers in the hills. However, some of them have crossed the Churia range and flown towards low land. Mechi, Kankai, Kamala, Thijuja, Rapti and Babai reach to the low land crossing the churia range and flow towards India.

The small rivers that originate from the Churia hills are called the rivers of third catagories. Therefore, they remain dry during dry season. Such rivers flood in the rainy season. They originate from the Churia range and reach up to the big rivers. Some of them reach up to Ganga also. Some of the rivers originated from Churia dismiss in the Terai region 
also. These rivers are not so important for irrigation and agriculture. However, they are important for sand and stones. All together there more than 6000 rivers in Nepal.

\section{Koshi River}

The Koshi River flows from eastern part of the country. It is the biggest river of Nepal. Its watershed area is from Kanchanjungha of east to the Gosaikunda of west. Some of the tributaries of Koshi River are originated from Tibet, therefore, it is an international river. It crosses from Tibet to Nepal and reaches to Ganga in Bihar India. Finally, it reaches in the Bay of Bengal. The area of watershed is $71500 \mathrm{sq} . \mathrm{km}$ as a whole and its area is only 30 thousand sq.km in Nepal. Out of $720 \mathrm{~km}$ length, it covers only 200 kilometer inside Nepal (Pandey, 2043: 87). Seven big rivers are mixed in this river and it is said Saptakoshi. It is named from the name of saint Kausiki. She is known as Parvati the concert of Lord Shiva (Koirala, 2050: 92). It flows down to the Ganga river from Korshila of Bihar, India.

\begin{tabular}{|l|l|l|l|}
\hline S.N. & Name of the river & Origin & Length KM \\
\hline 1 & Tamor & Janak M & 198 \\
\hline 2 & Arun & Tibet & 152 \\
\hline 3 & Dudhkoshi & Mahalangur M & 113 \\
\hline 4 & Likhu & Rolwaling M & 23 \\
\hline 5 & Tamakoshi & Tibet & 90 \\
\hline 6 & Sunkoshi & Tibet & 256 \\
\hline 7 & Indravati & Lamtang M & 68 \\
\hline
\end{tabular}

Source: Pandey, 2043.

Tamor River originates from the Janak mountain of Taplejung district. It flows toward southwest and reaches in Trivani. It is the southern branch of Saptakoshi river. The area of water shed is $6800 \mathrm{sqkm}$ and the length of this river is $198 \mathrm{~km}$. Dukhagni Bahari is the Samskrit name of Tamor river. It flows from the land of Limbu people. Kabeli is the biggest tributary of Tamor River. We cannot find any big settlement areas at the side of Tamor. However, many more rivers mix in this river and it is very important for the developmet of electricity and tourism. Thousands of big and small rivulets mix in this river. It is related with Limbu culture. Myaglung, Marga and other Devis lie at the watershed area of this river. Historically it is a river of medieval Vijayapur state. Pallo Kirat River is Tamor.

The second tributary of Koshi River is Arun, which is originated from Tibet. It has $4800 \mathrm{sqkm}$ water shed area in Nepal. Arun originates from Tibet and it is called Funchu there. It is $152 \mathrm{~km}$ long in Nepal. It enters Nepal from Kimathanka pass and it has the lowest valley in the world. Its valley is only 420 meter high from sea level. Its Samskrit Name is Mahaprabha Sibaduti. There are many branchs of Arun River. Among them, Barun is the most famous. It is called Barada Chamunda in Samskrit language. Khandabari and Chainpur 
are main settlement area beside Arun River. It is the river of Khumbuwan and it is in the boarder of Limbuwan and Khumbuwan. Manakamana, Siddhakali and Chintang Devi are main goddesses of this region. This river was originated earlier than the Himalayas.

Dudhkoshi, the third branch of Saptakoshi river originates from Mahalangur Mountain of Solukhumbu district. It originates from Mt. Everest and it is said a river of Mt. Everest. The water of this river seems white like milk and it is named milk river of Dudhkoshi. Its length and water shed areas are $113 \mathrm{KM}$ and $4100 \mathrm{sqkm}$. Bhadramati Chandi is its Sanskrit name. In the same way, Likhu is the shortest and the smallest tributary of Saptakoshi River. It oritinates from Rolwaling mountain and ends in Sunkoshi near Kilajar Ramachhap. It is $23 \mathrm{~km}$ long and it covers $800 \mathrm{sqkm}$ of land in watershed. It is a river of Rai people and culture. In the same way, Tamakoshi is other tributary of Saptakoshi River, which is called Papagni Narayani. It originates from Tibet and it reaches towards Sunkoshi in Ramechhap district. Its area of water shed is $2600 \mathrm{sqkm}$ and its length is $90 \mathrm{~km}$. Swarnakausaki is another tributary of Saptakoshi River, which originates from Tibet and it ends in Indravati in Dohalghat. It has a strong water wave, which is $256 \mathrm{~km}$ long. Its watershed area is $14100 \mathrm{sqkm}$. It is the river of Sunuwar.

Indrawati is the tributary of Saptakoshi River. It is originated from Lamtang Mountain, which flows towards east and ends at Sunkoshi in Dolalghat. It is $68 \mathrm{~km}$ long and it covers $1200 \mathrm{sqkm}$ of land with its water shed. Besides, there are many more streams and rivers, which mix in Saptakoshi river. From Trivani it flows towards south and reaches up to Chatara. Varahakshetra lies in the hillside of Koshi basin. Koka, another small tributary of Koshi River mixes in Koshi river near Varahakshetra. In the same way, Koshi reaches to the low land from Chatara. Varahakshetra and Chatara are the main holy places of this river. Ramdhuni and Pindeswara are also not so far from these localities. Chatara was known as Chetra in ancient period. In the same way, Varahakshetra was famous bathing place from Mahabharat period.

Saptakoshi is the river of Rai, Limbu, Arya, Sunuwar, Tharu, Dhimal, Satar and Bantar. Different ethnic people of this region worship this river. She is known as Parvati and the wife of lord Shiva. In the same way, local ethnic people worship it as the goddess of local origin. The Tantrikas also resite its name while chanting mantras of gods and goddesses. Saptakoshi River is famous for taking holy bath. Big fairs and festivals are organized each year in the name of Koshi River. Recently, Bala Santa has established the system of taking bath as Kumba snana in Chatara of Sundari district. This is done in the name of Pindeswara and Chatara. The system of Kumbha Snana has raised its value of bathing. The cultural value of Koshi River is given in Mahabharata (3.84.158) and Brahmapurana (119.1-140). Other religious texts also have given the value of Koshi River. 
Koshi River flows from the land of Kirati culture. The main residence of Kirati people remains in the hills of this river basin. Ollo Kirat and Pallo Kirat means Khumbuwan and Limbuwan lie in its basin. They follow Kirati religion. In the same way, the main land of Sherpa also lies in Koshi region. Solukhumbu is the main land of Sherpa. They follow Lamastic Buddhism. Other Buddhist people like Walung and Bhotia also reside in this region. Traditionally, they reside in High Mountain. Hence, low land is for local low land people and their culture. They are Tharu, Meche, Kishan, Dhimal, Rajvamshi and Santhals. Meche, Kishan, Dhimal and Rajvamshi are found only in this region. They follow Hinduism and some of them are nature worshipper. Therefore, Koshi region is rich with different cultures.

While talking about the religious sites Varahakshetra, Pathivara, Haleshi, Pindeswara, Chintang, Ramdhuni, Arjundhara and Satashidham are main religious centers of river basin. There are many more religious sites around the river basins, where the temples of gods and goddesses are made. Many people reach there in different occasions and perform religious activities. Therefore, Koshi is considered as a pious river and there are many more Tirthas at the water-shed area of this river. This river is very pious for sacrament and religious works. Hindu and Kirati people perform their ancister worship activities in Koshi river basin.

\section{Gandaki River}

Gandaki River flows from middle Nepal. Its name originated from the name of saint Gandak. Gandaki River originates from between Gosainkunda and Dhabalagiri Mountain. It is $338 \mathrm{~km}$ long and its water-shed area is about $46300 \mathrm{sqkm}$. However, only 40 thousand sqkm water shed area lies in Nepal (Pandey, 2043: 85). This river is called Narayani in Chitawan and Gandak in Bihar India. There are 1025 glaciers, thousands of streams and 338 lakes in its water shed area. However, there are main 7 tributaries of this river and it is said Saptagandaki. The main branches of this river are as follows.

\begin{tabular}{|l|l|l|l|}
\hline S.N. & Name of the river & Origin & Length KM \\
\hline 1 & Trisuli & Tibet & 362 \\
\hline 2 & Budhigandaki & Tibet & 117 \\
\hline 3 & Daraudi & Gorkha & 53 \\
\hline 4 & Marsyangdi & Damodar lake & 153 \\
\hline 5 & Madi & Annapurna M & 74 \\
\hline 6 & Setigandaki & Annapurna M & 127 \\
\hline 7 & Kaligandaki & Mustang & 316 \\
\hline
\end{tabular}

Source: Pandey, 2043.

Trisuli is the most important branch of Gandaki River. It origins from Tibet and flows down from the hills. Budhigandaki mixes with it in the beginning and then Marsyangdi, Madi and other rivers mix with it. Its watershed area is $4000 \mathrm{sqkm}$ and the length is 362 
KM. Historically, it was a boundary of Gorkha and the Malla kings of Kathmandu Valley. It is called Dharmavati Maheswari in Sanskrit language. Devighat is historical and religious center located at the bank of this river. Yasodhara Brahmayani is the name of Budhigandaki River, which is another branch of Gandaki River. It is originated from Tibet and flows 117 $\mathrm{km}$ inside Nepal. It mixes with Trisuli at Benighat and covers $3700 \mathrm{sqkm}$ with its water shed area.

Daraudi river is the shortest branch of Gandaki river. It originates from the mountain region of Gorkha district and falls into Marsyangdi River. It is $53 \mathrm{~km}$ long and $3500 \mathrm{sqkm}$ is its water shed area. In the same way Marsyangdi River covers 4600 sqkm water shed area with $153 \mathrm{~km}$ length. Biswadhara Narasingha is her Samskrit name given in Pauranic texts. In the same way Madi, another branch of Gandaki River originates from Annapurna Mountain and flows up to Seti river covering $74 \mathrm{~km}$ distance. It has the least water shed area covering $1100 \mathrm{sqkm}$. Seti Gandaki is another branch of Saptagandaki River (Khatiwada, 2068: 77). It is originated from Annapurna Mountain. With the length of $125 \mathrm{~km}$ and 2700 sqkm watershed area it flows through Pokhara valley making deep George.

Kaligandaki is one of the most important branch of Gandaki River. It is $316 \mathrm{~km}$ long and it covers $4300 \mathrm{sqkm}$ water shed area. It is known as a shaligram river. Shaligram is known as the form of lord Bishnu in Hinduism. She has different names like Ratnapravha Kaumari, Krishna Gandaki and Kaligandaki. It is originated from Naupine Mountain and mixes in Gandaki from Devaghat. It was older than the Himalayas. The deepest George remains in Kaligandaki basin. It is the deepest George which is 7000 meter deep. Myagdikhola, Jungkhola, Modikhola and Rahughatkhola etc. are its tributaries.

With its seven tributaries, Gandaki river has many other branches. It is the holiest river of Nepal and different kind of holy centers are at the bank of this river. Devaghat, Balmiki Ashram, Muktinath, Ridi and Trivani are some holy places located at the side of this river. Manakamana and Gorakhkali also are famous temples of Gandaki region. In the same way the temple of Barahi is located on an island of Phewa lake. It is said Saligram River and Saligram is the symbol of Vishnu for the Hindus (Pandey, 2000: 217). The water of this river seems black and it is said Kaligandaki. Other brances of Gandaki River are also famous and they have great religious value.

Gandaki region is the land of Gurung, Dura, Thakali, Magar, Danuwar, Kusunda and other tribes. It was famous from very ancient period. Malla ruled in ancient period in Gandaki region. At the time of Lichhavi period Mallapuri was there in this region. In the same way there were Chaubise states in medieval period. Therefore, Gandaki region was famous in historical period. 


\section{Karnali River}

Karnali is the longest river of Nepal. It originates from mid-western and far western Nepal. It is $507 \mathrm{~km}$ long and it covers 50 thousand sqkm of watershed land. It is known as Ghagra in India. Like others, it has seven tributaries. There are Se-phoksundo, Rara, Khaptad and Bardia national park and Dhorpatan hunting sites in its watershed area. Thousands of rivulets, lakes and waterfalls are there in its area. The main tributeries of Karnali river are as follows.

\begin{tabular}{|l|l|l|l|}
\hline SN & Name of the river & Origin & Length KM \\
\hline 1 & Saniveri & Rukum & 98 \\
\hline 2 & Thuliveri & Dolpa & 136 \\
\hline 3 & Tila & Jumla & 99 \\
\hline 4 & Mugukarnali & Mugu & 384 \\
\hline 5 & Humlakarnali & Tibet & 528 \\
\hline 6 & Budhiganga & Bajura & 84 \\
\hline 7 & Seti & Bajang & 202 \\
\hline
\end{tabular}

Source: Pandey, 2043.

Like other two rivers Karnali river also has seven main tributaries and it is called Saptakarnali. Among others, Sani Vheri begins from Swargadwari hill and the water of Himchuli mountain also goes throught this river. It is $98 \mathrm{~km}$ long and it covers $2300 \mathrm{sqkm}$ land in its whater shed area. In the same way Thuli Veri river originates from Araniko Chuli of Dolpa district. Having $3300 \mathrm{sqkm}$ water shed area it is $136 \mathrm{~km}$ long. In the same way Tila originates from the eastern part of Jumla. The water-shed area of Tila is $2400 \mathrm{sqkm}$ and the length is $99 \mathrm{~km}$. Another famous branch of Karnali River is Mugukarnali, which is originated from Gautam and Kanti mountain. It is $384 \mathrm{~km}$ of length and water shed area of this river is $6100 \mathrm{sqkm}$. Humla Karnali originates from Tibet and the water of Chandi and Gorakh Himal also goes up to this river. Main and the longest branch of Karnali river is Humla Karnali. It is $528 \mathrm{~km}$ long and it covers $6100 \mathrm{sqkm}$ in watershed. The shortest branch of Karnali river is Budhi Ganga. It has 1700 sqkm watershed area and its length is $84 \mathrm{~km}$. Seti is another branch of Karnali River which is originated from Chandi and Gorakh Himal. It flows from the western side of Karnali River. It is $202 \mathrm{~km}$ long and its area is $7500 \mathrm{sqkm}$.

Karnali is the longest river of Nepal. Humla Karnali River is originated from Tibet but others are originated from the side of Karnali and Seti Zone. It is the land of Khasha and there is a long history of Khasa in this region. Worshipping Masto is another features of this region. Specially, Thakuri, Magars and other ethnic groups are there in this region. In medieval period Khasha culture was developed. Nepali language was originated in this region. Both Hinduism and Buddhism were developed in this region. Karnali river is famous for Masta worship. In the same way Badi Malika, Tripura Sundari, Khaptad and other centers 
of gods and goddesses are famous in this region. Deuda is a popular folk song and dance of this region. This region is the primary place of different groups of people in Nepal. The most western river of Nepal is Mahakali. It is a boarder river of Nepal.

Mechi, Kankai, Trijuga, Kamala, Bagmati, Rapti, Babai, Tinau and Banganga are other rivers of Nepal which are divided into second category. Among them Bagmati is the longest river. It originates from Bagdwar and flows through Kathmandu valley. Pashupati, Guheswari, Dakshinkali and other more sacred places and Tirthas lay in the bank of this river. Therefore, the culture of Bagmati is very important. In the same way Mithila lies in the bank of Kamala river. It is $107 \mathrm{~km}$ long. Ancient Janakpur is at the side of Kamala river. Historically Kankai River of the east has also a great importance. It originates from Mai Pokhari area of Illam district and flows through Jhapa district. Mai Pokhari, Maidhar, Satashidham and Kotivata are main religious places of this region. Meche, Kishan, Rajvamshi, Santhal and Dhimal are main ethnic groups of this region (Khatiwada, 2068: 67). Trijuga is other river, which flows from the valley of Udayapur. It is a main center of Danuwar people. In the same way, there are two Rapati rivers in Nepal. One flows from Dang valley and the other from Makawanpur. Makawanpur Rapati is related with Chepang people, where as Dang Rapati is closely related with Tharu community of western Nepal. Babai, Tinau and Banganga also has the great historical value. Ancient Kapilvastu lies in the bank of Banaganga River. We can find the remains of Kapilvastu at the bank of Banaganga river.

Balan, Bakraha, Ratuwa, Mainavati, Lakhandevi, Manusmara, Jamuni, Hardinath, Rohini, Kothi, Surahi, Mohana, Chisang, Budhi and Seuti are third catoried rivers which originate from Chure range and flow towards south. They are not long and they are less important. They remain dry in winter season. However, they remain full of flood water in summer season. There are more than six thousand rivers in Nepal. Many of them are originated from the Snow Mountains and water flows whole the year from these rivers. Continuous water flows from second categories rivers also. However, the third catagories river remain dry in dry season. It floods only in rainy season.

\section{River Culture}

Nepalese culture based on the river activities. They are the centre of civilization and most of our cultural activities are related with the river. Most of our religious centers are located on the river banks. Therefore, rivers are known as holy centers in our culture. Most of our cultural activities are related in the river. Our rites from birth to the death are related with river and Sangamas. In Nepalese culture, rivers are the centers of taking bath, doing different sacraments and performing worship for the gods goddesses. The rivers are known as goddesses themselves. All the rivers in Nepal are known as Parvati or holy Gangas. Therefore, most of the religious, sacramental and cultural activities are concentrated at the bank of the river. The main cultural activities performed in the riverside are as follows. 


\section{Organization of the festivals}

Festivals carry the cultural values and most of the festivals are related to the religious activities. Some of them are organized along the river side (Anderson, 1988: 79). Makarsamkranti, Rishirarpani, Rishipanchami and Chhaith are close related with riverside. People take a holy bath in the occasion of festival on the river bank. River are clean and holy and they are the means of cleanliness in organizing the festivals. Rivers are known as the goddess Ganga in Nepalese culture and it is believed that gods also reside on the banks of the river. Therefore, most of the sacred centers lie along the bank of Nepal and some festivals are organized along river banks.

\section{Management of Mela and jatras}

Some of Jatras and Melas are related with the river bank. For example, Gangamai Jatra is organized in the bank of Bagmati River of Kathmandu. In the same way, Arati of Bagmati is also performed in this centre. Taking a holy bath and organizing of the Jatras is the main cultural activity along the river culture in Nepal. Makara Mela, Kumbha Mela, Chhat, Rishipanchami, Rishitarpani and other festival are celebrated on the bank of river and Melas are organized in such centres.

\section{Centre of holy bath}

Rivers are the centre of holy bath in Nepal. There are many occasions to take a holy bath in the river side. For example Makara Snana and Kumbha Snana are the most important. This festival is organized on the $1^{\text {st }}$ day of Magha. Thousands of people gather on the riverbank to take a holly bath in the occasion of Makarsamkranti. Narayanghat, Triveni, Varahakshetra, Pashupati area and Ridi are important river sides to take Makar Snana. In the same way, Kumbha Snana conducted on the riverside. There are four famous centers for Kumbha Snana in India. However, we have also some centers of Kumbha Snana in Nepal. They all are located on the riverbanks of Nepal. Chatara near Varahakshetra, Devaghat and other holy centers are famous for Kumbha as well as the Makara Snana in Nepal.

\section{Beginning and ending of Bratas}

We have a system of taking bath before worshipping the gods and goddesses in the temple. Some Bratas or fast are also started after taking holy bath in the holy rivers. Therefore there are some Snana Ghatas in the Holy rivers of Nepal. For example Aryaghat of Pashupati area is a Snanaghata. It is known as Arya Tirtha in Himavatkhanda Purana (Yogi, 2013: 691). Therefore, people take a bath there before worshipping the lord Pashupatinath. In the same way people take a bath before ending their salvation or Bratas. Kokamukha of Varahakshetra, Maidhar of Jhapa, Triveni of Navalparashi, Tahanu, Ridi and other centers are famous places to take a bath before and ending Bratas. So, rivers are the centers of holy bath in Nepal. 


\section{Kalpavasa and Ajivana Vasa}

Rivers are the centers for Antesty Kriya in Nepalese culture. The dead body is desposed on the river banks. Rivers are the holy objects and it is believed that the gods and goddesses reside there. According to a Hindu religious belief, a person dying on the lap of the gods and goddesses can get the chance to reside in the heaven. Therefore, there is a system of Kaplabasa in the holy centers of riverside. There is the system of Ajivana Basa along the Ghats aiming to die there and reach heaven.

\section{Antesty Kriya}

According to our culture, the dead body of a person should be disposed on the riverbank, so that the dead person can easily reach heaven. Astu Kshepan and Shraddhas are also done on the riverside for salvation.

Rivers are the center of the cultural activities of Nepal. In one hand, they are regarded as the center of gods and goddesses. Rivers themselves are known as Ganga or the goddesses. Therefore, most of the gods and goddesses are belived to be residing on the bank of river. That is why most of our culture activities are connected with river. For example they are holy and people take the holy bath there. Makara Snana, Kumbha Snana, Rishitarpani Snana and Rishi Panchami Snana are famous occasion of Snana in the riverside. In the same way Chhait is totally related with the river activity. Taking bath before worshipping gods and goddesses of the temple, starting and ending of Bratas and doing sacraments is done along the riverside. Kalpabasa, Antesti Kriya, Gods and Pitri related activities and most of the cultural performances are related with the river. In short, rivers are regarded as a bridge to cross the physical and spiritual body and reach to the heaven in Nepalese culture. Therefore, Nepalese culture and rivers are like two sides of the same coin.

\section{Conclusion}

Nepali culture is closely related with river and water. Most of the sacred places are located along the bank of the big rivers. Varahakshetra, Devaghat, Rurukshetra, Maidhar, Kathmandu, Janakpur, Kapilvastu and Muktinath are at the side of rivers. Rivers themselves are worshipped as the goddess by Nepali people. Therefore, they are called Mata or mother. For example, Kankaimai, Kausikimata and Narayani Mai are some examples of worshipping rivers as mother. Even the ethnic people offer or maccare the animals in the name of river goddesses. Sometimes she is worshipped as Jalakanya also. Water pollution is culturally prohibited and polluting water is taken as a serious sin in traditional Hindu system. Ancient cities were located along the river side.

Rivers are the objects of holy bath for the Nepali people. Especially confluences are believed more sacred to take. There are different occasions for taking a bath in the rivers. Kumbha Snana, Makar Samkranti, beginning and ending of Bratas, Chhait, Rishipurnima 
and Rishitarpani are some special occasions. Almost all sacraments of Nepali people are related to water and the river. Most of the sacraments are done along the riverside. For example dead body is disposed in the river. In the same way, other rites related on death sacraments are also done there. The remaining portion of the sacraments and other yajnas are conducted after the holy bath in the river. In this way it is believed that gods, goddesses and ancestors (Pitris) reside the water and river. The gods living in the water is called Jaladevata. Each activities of the Nepali culture are closely related with river. Therefore, we can say that Nepalese culture is river culture.

\section{References}

Aderson. M.M. (1988). The Festivals of Nepal, Delhi: Rupa and Co.

Dutta. S. (ed. 2045). Mahabharat Part 1-6, $6^{\text {th }}$ ed. Gorakhapur: Gita Press.

Khatiwada. S (2068). Impact of river civilization in Nepali folk culture, Kathmandu: A research report submitted in Nepal Academy under Viddwat Vritti Program.

Koirala. K. (2050). Nepali Samskritik Jatra, Parva, Kathmandu: K K Smriti Pratisthan.

Pandey. R.K. (2043). Geography of Nepal, Lalitpur: Centre for Altitude Geography.

Pandey. R.N. (2000). Sacred Complex of Rurukshetra, New Delhi: Adroits Publishers.

Shastri. R.D. (1991). Brahma Puranam, Gorakhapur: Gita press.

Yogi., N.H.N. (2013). Skanda Purana Himavatkhanda, Baranashi: Yoga Tilla. 